\title{
Load test of new European record holder in span length among extradosed type bridges
}

\author{
Mikołaj Miśkiewicz ${ }^{1, *}$, and Łukasz Pyrzowski ${ }^{1}$ \\ ${ }^{1}$ Dep. of Mechanics of Materials and Structures, Faculty of Civil and Environmental Engineering, Gdańsk University of Technology, G. \\ Narutowicza 11/12, 80-233 Gdańsk, Poland
}

\begin{abstract}
The article presents acceptance load tests of a newly built extradosed MS-3 bridge located along the national road DK-16 near Ostróda (Poland). The structure features significant dimension in European reference scale. It is a new record holder in span length regarding this distinct bridge category. Its length ranges $206 \mathrm{~m}$. Static and dynamic load tests were performed here. The program was extended by entire structural laser scanning and identification of natural vibration forms.
\end{abstract}

\section{Introduction}

An extradosed bridge is a structure combining the technical solutions for a prestressed box girder bridge and a cable-stayed bridge [1]. The extradosed concept precursors are Ganter Bridge in Switzerland and bridge in Rzuchów in Poland, both built in 1980. Nevertheless, Jacques Mathivat is most commonly credited as an inventor of extradosed terminology and its design concepts by publishing his ideas in 1988 [2]. Since that time, this type of a bridge is under current development and new modern, record-breaking structures are permanently erected. Currently the world longest extradosed bridge, according to structurae.net, is ArrahChhapra Bridge in India with $1920 \mathrm{~m}$ of total main bridge length (16 spans, $120 \mathrm{~m}$ each), built in 2017. In turn, the longest span world record belongs to Kiso Gawa Bridge in Japan, $275 \mathrm{~m}$ long. The European bridges reach lower achievements. However, one of the records belongs to a Polish structure. It started in 2013, when the extradosed bridge was completed in Kwidzyn over Vistula River. This structure, with its main span length of $204 \mathrm{~m}$, became the record holder in this category in Europe [3]. Recently, at the end of 2017, the bridge MS-3 construction was finished along the road DK-16 near Ostróda. The structure was designed by Transprojekt Gdański Sp. z o.o. and erected by Budimex S.A. The longest European span length achievement has been taken over and raised up to $206 \mathrm{~m}$. The paper deals with the acceptance tests of this bridge, undertaken 14th of December 2017. The tests were designed and performed by Bridge Laboratory of Department of Mechanics of Materials and Structures at Gdansk University of Technology and Aspekt Laboratorium Sp. $\mathrm{z}$ o.o. Due to the fact of significant structural size in European scale, the tests have been assumed an extended program, related to typical structure, including e.g. structural laser scanning. The load tests were prepared and performed taking into account experience of the paper authors [4-12] as well as other contributors in the field [13-23].

\section{Structure description}

The MS-3 bridge is located along the national road DK16 , designed to cross the deep valley and the Ornowska Struga stream near Ostróda. It is a continuous four-span structure, in its majority made of prestressed concrete. It includes three short towers (deviators) and a system of stayed cables, to be eventually called an extradosed bridge, see Figure 1.

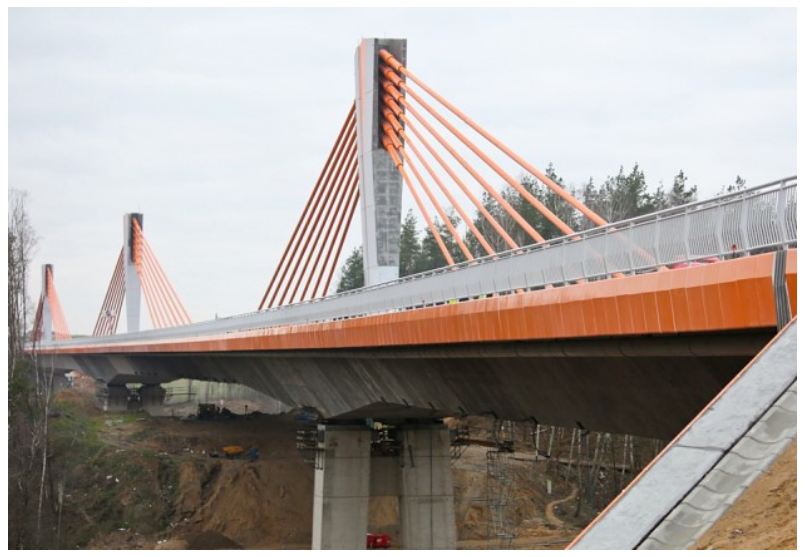

Fig. 1. Side view of MS-3/DK-16 bridge.

The theoretical total structural length is $677 \mathrm{~m}$, the spans lengths are $132.5 \mathrm{~m}, 206.0 \mathrm{~m}, 206.0 \mathrm{~m}$ and 132.5 $\mathrm{m}$. The towers rise above the deck to a height of $23 \mathrm{~m}$. They are made of C60/75 reinforced concrete (two pylons) and prestressed concrete (one pylon). The total deck width is $28.6 \mathrm{~m}$, consisting of two roadways, three service sidewalks and four bands. The deck structure is a three-chamber box made of prestressed C60/75 concrete,

\footnotetext{
* Corresponding author: mmisk@pg.edu.pl
} 
see Figure 2. The height of the box varies between $\sim 4 \mathrm{~m}$ in spans up to $\sim 6 \mathrm{~m}$ above middle supports. Steel of a characteristic $1860 \mathrm{MPa}$ strength is used for prestressing, while A-IIIN B500SP steel is used for soft reinforcement. The external prestressing on each pylon is carried out with the use of 167L15.7 tendons for the three longest cables, 139L15.7 for two consecutive intermediate cables and $135 \mathrm{~L} 15.7$ for two shortest cables. The bridge is designed for the highest load class A according to Polish standard [24].

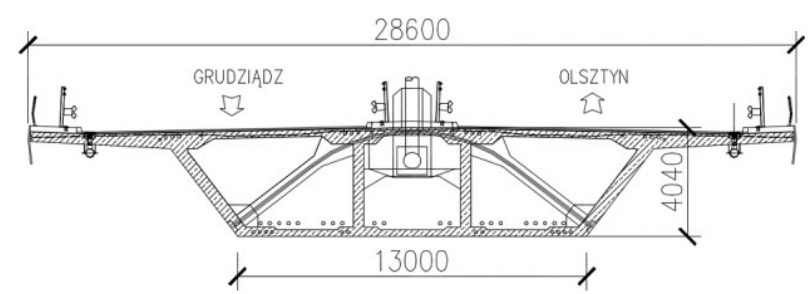

Fig. 2. Typical cross-section of MS-3/DK-16 bridge.

\section{Computational analysis}

In order to create the acceptance load test program, i.e. ballast choice selection of measurement points location and adequate sensor choice, it was necessary to create a relevant numerical model of the structure. The Finite Element Method (FEM) model (see: [25] and [26]) was made within the SOFiSTiK system, see Figure 3.

The adopted model involves three finite element types, marked with symbols $(\mathrm{R}),(\mathrm{P})$ and $(\mathrm{K})$ :

(R): 1-dimensional, 2-node, Timoshenko spatial rod-type elements, class $\mathrm{C}^{\circ}$ with linear shape functions, considering shear effect and eccentricity of the beam axis: 1650 elements;

(P): 2-dimensional, 4-node, Timoshenko-Reissner shelltype elements, class $\mathrm{C}^{\circ}$ with bi-linear shape functions and deformation enhancement in the surface including shear and eccentricity: 161289 elements;

(K): 1-dimensional, 2-node, spatial truss-type elements, class $\mathrm{C}^{\circ}$ with linear shape functions: 42 elements.

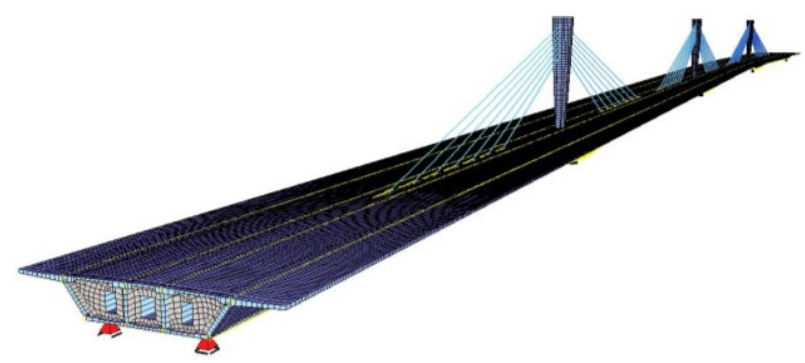

Fig. 3. Numerical model of MS-3/DK-16 bridge.

In the course of static simulations displacements, internal forces and stresses were determined in individual structural components under the action of standard-based road loads and the test load setting schemes. The results of dynamic calculations were frequencies and modal shapes of natural vibrations.

\section{Static tests}

In the course of static tests three different load settings were implemented. The ballast was assumed in the form of 5-axle vehicles, each one of a total $442 \mathrm{kN}$ weight. Two settings (U34 and U45) were designed to obtain maximum cross-sectional bending moment in the middle of spans 3-4 and 4-5, respectively (16 vehicles in each test), the third one (U3) to obtain minimum crosssectional bending moment above P3 support (36 vehicles). The extreme values of the above parameters were established in the range of $75-100 \%$ compared to the results obtained for a road load model according to [24]. The load settings U34 and U45 are shown in Figures 4 and 5.

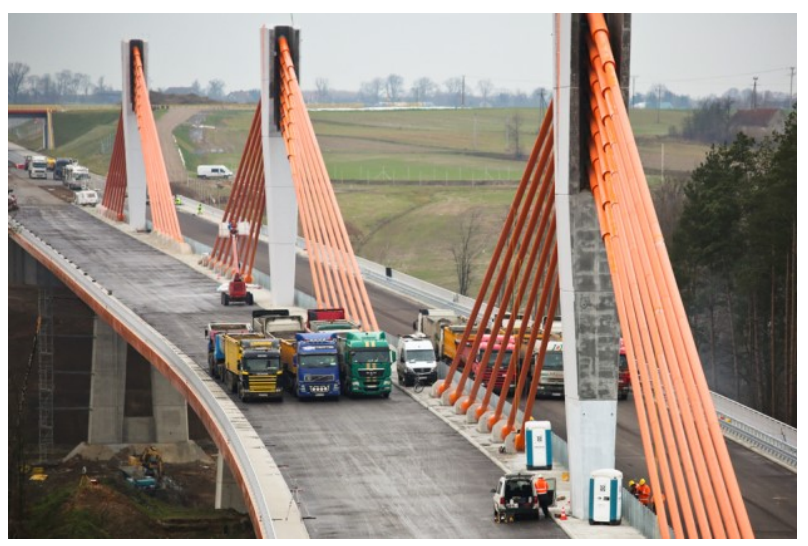

Fig. 4. Full ballast loading during U34 setting.

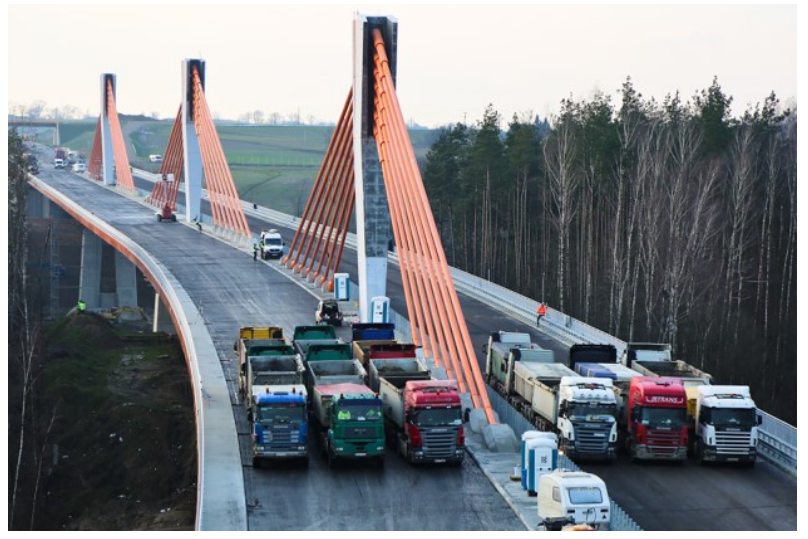

Fig. 5. Full ballast loading during U45 setting.

In the coverage of load tests, the following measurements were performed:

- vertical displacements of the span by means of precise levelling (Carl Zeiss Ni007), optical tachymeters (LEICA NOVA TM 50) and dial gauges: 17 sections, 2 points per each located at the ends of cantilevers $=34$ measurement points,

- three-directional displacements of pylons by an optical tachymeter (LEICA NOVA TM 50): 3 measurement points,

- force in cables by accelerometers using vibration method (APEK, AV32M37R4.6U16): 8 measurement points, 
- stress (strain) of the deck by stringed extensometers (GEOKON 4000A-1): 2 measurement points located at bottom plate of the girder box,

- settlement of supports by means of precise levelling (Carl Zeiss Ni007): 8 measurement points.

The localisation of all measurement points due to static load tests is presented in Figure 6A.

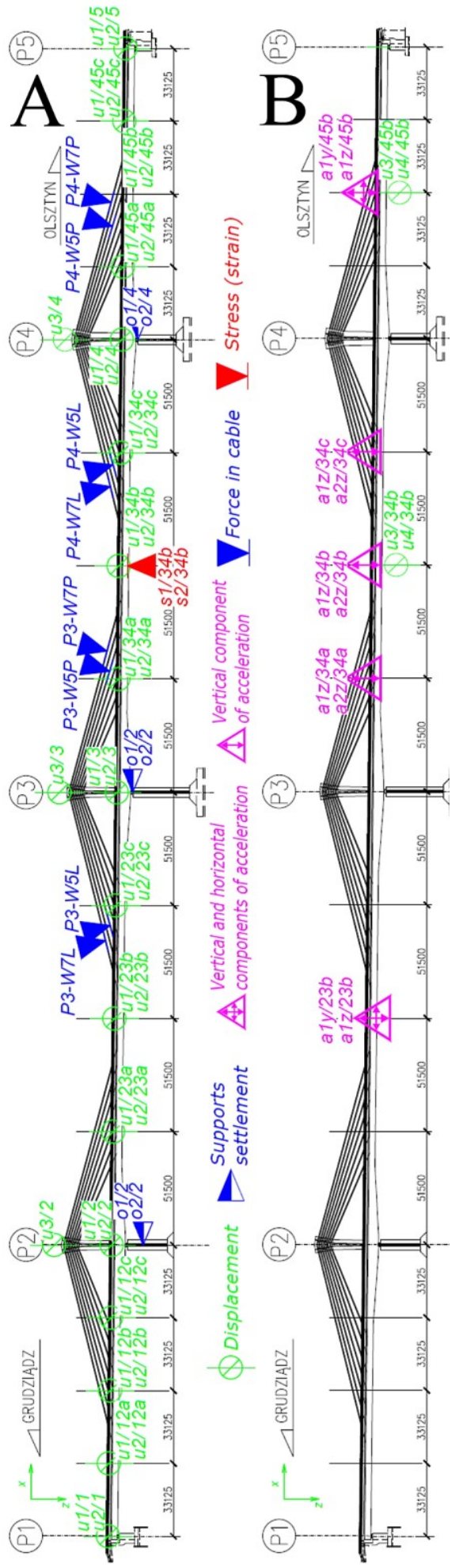

Fig. 6. Measurement point localisation for static load tests: left side (A), dynamic load test: right side (B).
Table 1 presents middle span vertical displacements measured during static settings with reference to the theoretical values.

Table 1. Measured and calculated middle span vertical displacements of deck obtained in static tests.

\begin{tabular}{|c|c|c|c|c|}
\hline $\begin{array}{c}\text { Ballast } \\
\text { setting }\end{array}$ & $\begin{array}{c}\text { Measure } \\
\text { point }\end{array}$ & $\begin{array}{c}\text { Elastic } \\
\text { displ. Uz } \\
\text { [mm] }\end{array}$ & $\begin{array}{c}\text { Theoret. } \\
\text { displ. Uz } \\
\text { [mm] }\end{array}$ & $\begin{array}{c}\text { Accuracy } \\
{[\%]}\end{array}$ \\
\hline \multirow{2}{*}{ U34 } & $\mathrm{u} 1 / 23 \mathrm{~b}$ & -55.5 & -85.4 & 65 \\
full load & $\mathrm{u} 1 / 34 \mathrm{~b}$ & 155.0 & 183.0 & 85 \\
& $\mathrm{u} 1 / 45 \mathrm{~b}$ & -49.5 & -66.6 & 74 \\
\hline \multirow{2}{*}{ U45 } & $\mathrm{u} 1 / 34 \mathrm{~b}$ & -50.4 & -64.5 & 78 \\
full load & $\mathrm{u} 1 / 45 \mathrm{~b}$ & 56.5 & 92.9 & 61 \\
\hline \multirow{2}{*}{ U3 } & $\mathrm{u} 1 / 23 \mathrm{~b}$ & 35.5 & 55.1 & 64 \\
full load & $\mathrm{u} 1 / 34 \mathrm{~b}$ & 44.7 & 55.2 & 81 \\
& $\mathrm{u} 1 / 45 \mathrm{~b}$ & -11.8 & -18.3 & 64 \\
\hline
\end{tabular}
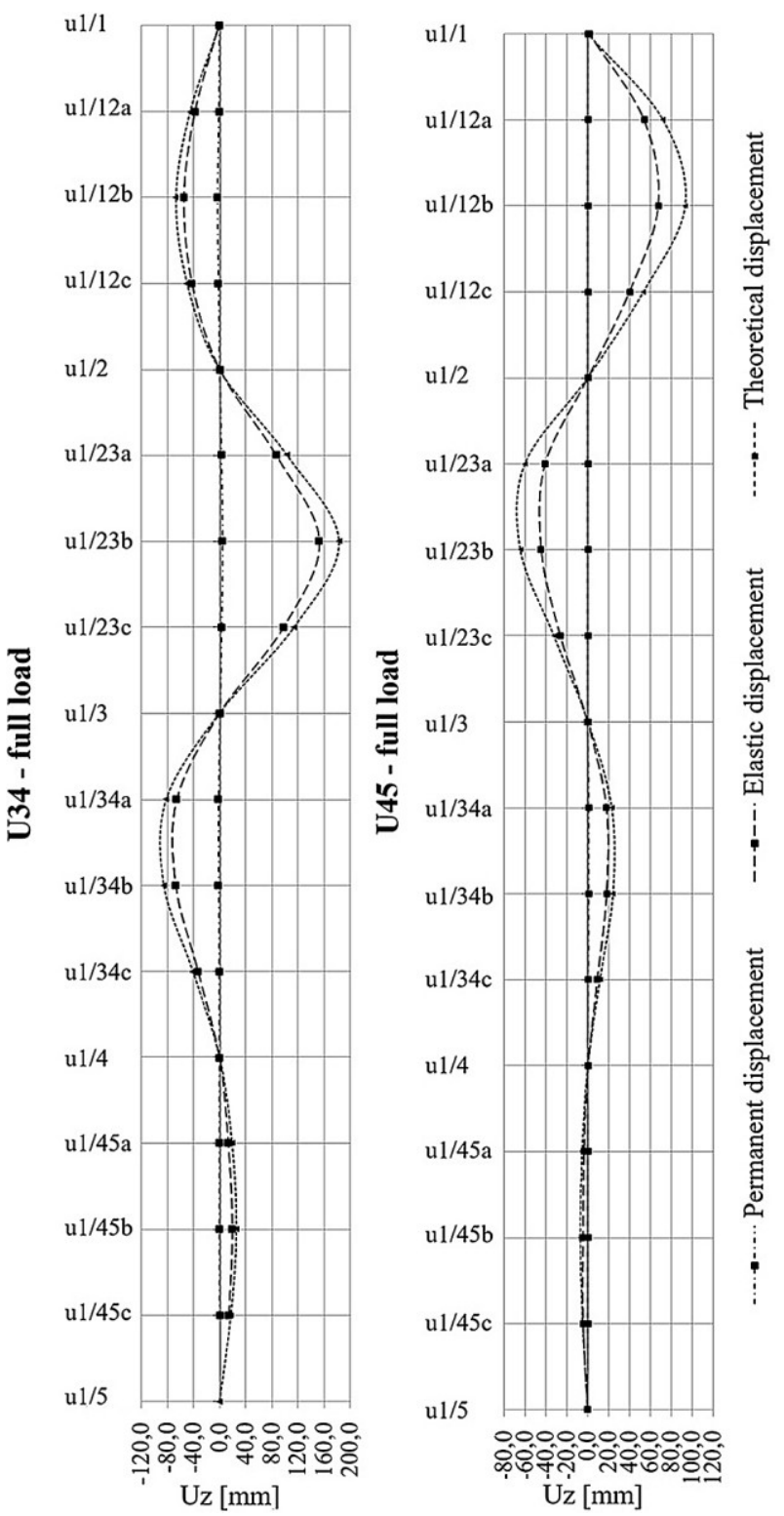

Fig. 7. Measured and calculated displacements along the structure obtained in U34 and U45 static settings. 
Figure 7 shows example results of vertical displacements along the bridge due to full U34 and U45 settings, compared with the theoretical values. Table 2 presents horizontal displacements of the pylons and Table 3 force increments in external cables, both referred to the theoretical values.

Table 2. Measured and calculated horizontal displacements of pylons obtained in static tests.

\begin{tabular}{|c|c|c|c|c|}
\hline $\begin{array}{c}\text { Ballast } \\
\text { setting }\end{array}$ & $\begin{array}{c}\text { Measure } \\
\text { point }\end{array}$ & $\begin{array}{c}\text { Elastic } \\
\text { displ. } \\
\text { Ux } \\
{[\mathbf{m m}]}\end{array}$ & $\begin{array}{c}\text { Theoret. } \\
\text { displ. } \\
\mathbf{U x} \\
{[\mathbf{m m}]}\end{array}$ & $\begin{array}{c}\text { Accuracy } \\
{[\%]}\end{array}$ \\
\hline U34 & $\mathrm{u} 3 / 2$ & -9.9 & -5.7 & 174 \\
full load & $\mathrm{u} 3 / 3$ & 31.0 & 52.6 & 59 \\
& $\mathrm{u} 3 / 4$ & -31.8 & -28.3 & 112 \\
\hline \multirow{2}{*}{ U45 } & $\mathrm{u} 3 / 2$ & 2.7 & 1.7 & 159 \\
full load & $\mathrm{u} 3 / 3$ & -8.2 & -15.1 & 54 \\
& $\mathrm{u} 3 / 4$ & 19.8 & 27.8 & 71 \\
\hline \multirow{2}{*}{$\mathrm{U} 3$} & $\mathrm{u} 3 / 2$ & 5.9 & 9.9 & 60 \\
full load & $\mathrm{u} 3 / 3$ & 0 & 0 & 100 \\
& $\mathrm{u} 3 / 4$ & -7.2 & -10.0 & 72 \\
\hline
\end{tabular}

Table 3. Measured and calculated forces in selected cables obtained in static tests.

\begin{tabular}{|c|c|c|c|c|}
\hline $\begin{array}{c}\text { Ballast } \\
\text { setting }\end{array}$ & $\begin{array}{c}\text { Measure } \\
\text { point }\end{array}$ & $\begin{array}{c}\text { Measur. } \\
\text { force } \\
\text { incr. } \\
{[\mathbf{k N}]}\end{array}$ & $\begin{array}{c}\text { Theoret. } \\
\text { force } \\
\text { incr. } \\
{[\mathbf{k N}]}\end{array}$ & $\begin{array}{c}\text { Accuracy } \\
{[\%]}\end{array}$ \\
\hline \multirow{3}{*}{ U34 } & P4-W7L & 644 & 636 & 101 \\
full load & P4-W5L & 615 & 636 & 97 \\
& P4-W5P & 495 & 575 & 86 \\
& P4-W7P & 326 & 318 & 103 \\
\hline \multirow{4}{*}{ U45 } & P4-W7L & -35 & 57 & 61 \\
full load & P4-W5L & 201 & 238 & 84 \\
& P4-W5P & 315 & 323 & 98 \\
& P4-W7P & 490 & 525 & 93 \\
\hline \multirow{3}{*}{ U3 } & P4-W7L & 162 & 167 & 97 \\
full load & P4-W5L & 150 & 177 & 85 \\
& P4-W5P & 130 & 163 & 80 \\
& P4-W7P & 77 & 93 & 83 \\
\hline
\end{tabular}

\section{Dynamic tests}

Dynamic tests were carried out based on structural excitation using 5-axle vehicle passes, each vehicle of a total $442 \mathrm{kN}$ weight. The basic tests included passes of a single vehicle with speeds: $10,30,50,70$ and $90 \mathrm{~km} / \mathrm{h}$ and two vehicles with speeds: 10 and $30 \mathrm{~km} / \mathrm{h}$. Additional tests included passes of a single vehicle by a threshold with 10 and $30 \mathrm{~km} / \mathrm{h}$ speed variants. In addition, the frequency and form of natural vibrations were identified using a LMS measurement set and a modal hammer.

In the course of dynamic tests structural response was recorded with the following instruments:

- vertical span displacements by inductive sensors (NOVOTECHNIK): 4 measurement points,

- acceleration by accelerometers (APEK, AV32M37R4 .6U16 and PCB Piezotronics, 393A03): 10 measurement points.

The localisation of all measurement points due to dynamic load tests is presented in Figure 6B.
Figures 8 and 9 display example results, i.e. vertical displacement time history at the $\mathrm{u} 3 / 34 \mathrm{~b}$ measurement point during $70 \mathrm{~km} / \mathrm{h}$ vehicle passage and vertical acceleration time history at a1z/45b during $30 \mathrm{~km} / \mathrm{h}$ vehicle passage with a threshold. The structure detects high resistance to dynamic excitations. The analysis of all vehicle passages allowed to estimate the dynamic increase factor $\varphi=1.01$.

The results recorded during vehicle passages extended by modal hammer excitations allowed to identify natural vibration frequencies and modes for the bridge. Table 4 presents the obtained natural frequencies of the bridge.

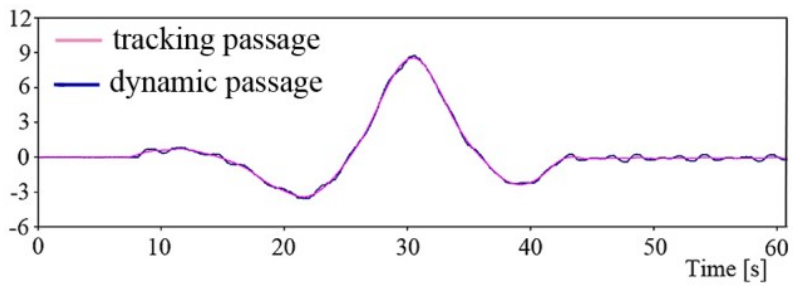

Fig. 8. Vertical displacement time history at point $u 3 / 34 b$ excited by a passing vehicle with a $70 \mathrm{~km} / \mathrm{h}$ speed.

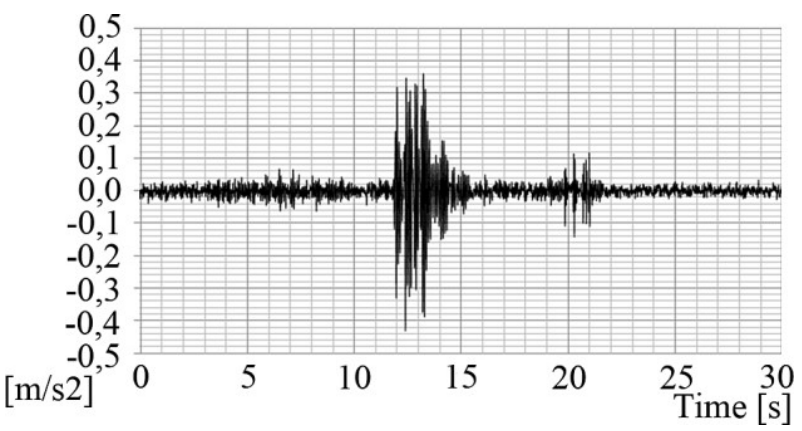

Fig. 9. Vertical acceleration time history at point a1z/45b during a $30 \mathrm{~km} / \mathrm{h}$ vehicle passage with a threshold.

Table 4. Identified and calculated natural frequencies of the bridge.

\begin{tabular}{|c|c|c|c|}
\hline $\begin{array}{c}\text { Mode } \\
\text { shape }\end{array}$ & $\begin{array}{c}\text { Measured } \\
\text { frequency } \\
{[\mathbf{H z}]}\end{array}$ & $\begin{array}{c}\text { Theoretical } \\
\text { frequency } \\
{[\mathbf{H z}]}\end{array}$ & $\begin{array}{c}\text { Accuracy } \\
{[\%]}\end{array}$ \\
\hline 1 & 0.31 & 0.35 & 89 \\
\hline 2 & 0.49 & 0.55 & 89 \\
\hline 3 & 0.74 & 0.95 & 78 \\
\hline 4 & 0.91 & 1.10 & 83 \\
\hline 5 & 1.21 & 1.25 & 97 \\
\hline 7 & 1.50 & 1.55 & 97 \\
\hline 8 & 1.67 & 1.65 & 101 \\
\hline
\end{tabular}




\section{Structure scanning}

Nowadays laser scanning is a useful tool for structural geometry assessment during their life cycle. If the scan is made just after competition of e.g. a bridge, the information about its original geometry is stored, to be freely applied in the future [27-33].

At the end of load test performance an entire structural laser scan was completed by Leica P30 (Figure 10). A thorough, spatial image of bridge geometry was achieved by the use of 96 stations and a grid of $1 \mathrm{~mm} \times 1$ $\mathrm{mm}$. The position alignment was completed by the least square method with an error not exceeding $5 \mathrm{~mm}$. The created point model of the bridge (Figure 11) can be used to analyse geometry, creating cross-sections (Figure 12) and comparing the scans from two different measurement periods in any point of the structure.

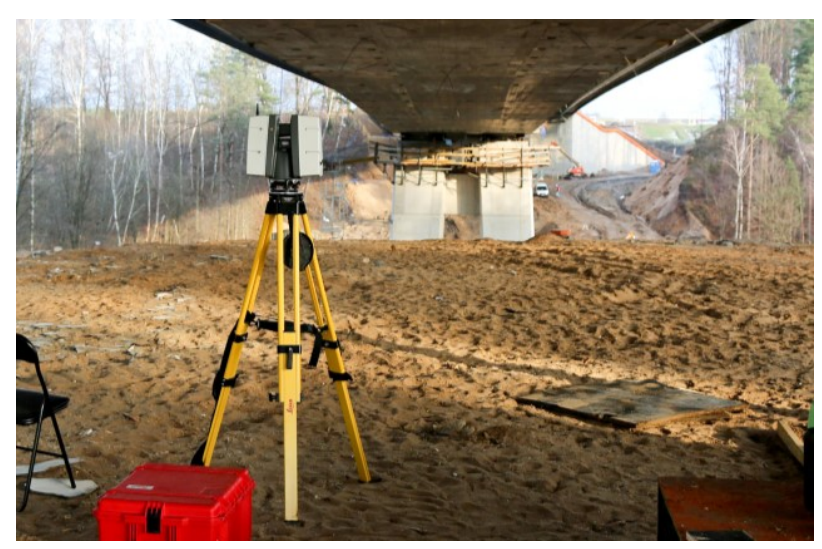

Fig. 10. Laser scanner Leica P30 station.

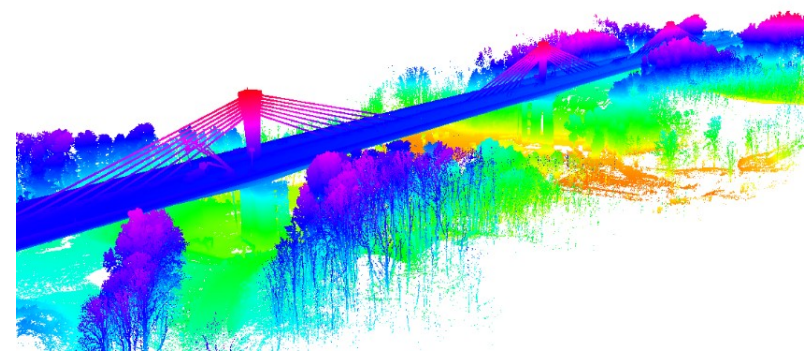

Fig. 11. Point model of MS-3/DK-16 bridge.

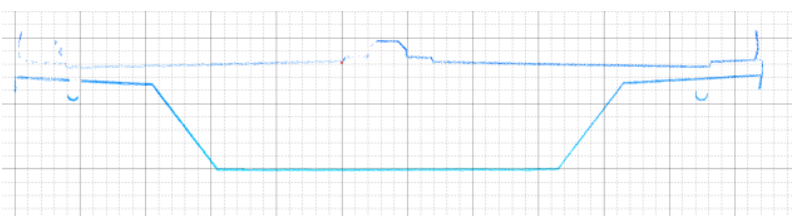

Fig. 12. Example section of bridge deck obtained in laser scanning.

\section{Conclusions}

The acceptance load tests were carried out in accordance with the program covering both static and dynamic parts. The tests were closed with a positive result: the structural response to ballast and dynamic excitations met the expectations. The spatial structural stiffness is higher than previously assumed in numerical analysis. The maximum registered vertical displacement of the deck during full load of U34 setting is $157.50 \mathrm{~mm} \pm 2.5$ $\mathrm{mm}$, i.e. $85 \%$ of the theoretical value. The average ratio of elastic values measured to the theoretical ones ranges $70 \%$. Permanent displacements of the spans are up to $2.50 \mathrm{~mm} \pm 0.1 \mathrm{~mm}$, not exceeding the limit values. The structure presents high resistance to dynamic excitations. Laser scan of the structure is a valuable geometry information base to monitor the structural performance in the future.

\section{Acknowledgement}

The authors wish to acknowledge the work provided by the others members of the research team: prof. K. Wilde, prof. J. Chróścielewski, prof. M. Rucka, Ł. Filar, R. Kedra, J. Kałuża, K. Makowska, B. Meronk, B. Sobczyk, P. Tysiąc as well as the bridge designer $\mathrm{T}$. Stefanowski for his support.

\section{References}

1. D. Collings, A. S. Gonzalez, Extradosed and cablestayed bridges, exploring the boundaries, Proceedings of the Institution of Civil Engineers Bridge Engineering 166 (4), 231-239 (2013) DOI: 10.1680/bren.10. 00058

2. J. Mathivat, W.F. Crozier, FIP Notes 2, 15-21 (1988)

3. J. Biliszczuk, J. Onysyk, W. Barcik, R. Toczkiewicz, A. Tukendorf, Frontiers in Built Environment 2, (2017) DOI: 10.3389/fbuil.2016. 00037

4. M. Miskiewicz, Ł. Pyrzowski, K. Wilde, J. Chróścielewski, J. Kałuża, Load testing of a suspended footbridge in Radom (Poland), Shell Structures: Theory and Applications 4 CRC Press/Balkema, 437-440 (2018)

5. M. Miskiewicz, Ł. Pyrzowski, Load Tests of the Movable Footbridge Over the Port Canal in Ustka, 2017 Baltic Geodetic Congress (BGC Geomatics), IEEE Xplore Digital Library (2017) DOI: 10.1109/bgc.geomatics.2017.7

6. Ł. Pyrzowski, M. Miśkiewicz, J. Chróścielewski, K. Wilde, Load Testing of GFRP Composite UShape Footbridge, IOP Conference Series: Materials Science and Engineering 245, 032050 (2017) DOI: 10.1088/1757-899x/245/3/032050

7. M. Miskiewicz, Ł. Pyrzowski, K. Wilde, Structural Health Monitoring System for Suspension 
Footbridge, 2017 Baltic Geodetic Congress (BGC Geomatics), IEEE Xplore Digital Library (2017) DOI: $10.1109 /$ bgc.geomatics.2017.8

8. M. Miskiewicz, Ł. Pyrzowski, J. Chroscielewski, K. Wilde, Structural Health Monitoring of Composite Shell Footbridge for Its Design Validation, 2016 Baltic Geodetic Congress (BGC Geomatics), IEEE Xplore Digital Library (2016) DOI: 10.1109/bgc.geomatics.2016.48

9. A. Mariak, M. Miśkiewicz, B. Meronk, Ł. Pyrzowski, K. Wilde, Reference FEM model for SHM system of cable-stayed bridge in Rzeszów, Advances in Mechanics: Theoretical, Computational and Interdisciplinary Issues, 383-387 (2016) DOI: 10.1201/b20057-82

10. M. Rucka, W. Witkowski, J. Chroscielewski, S. Burzynski, K. Wilde, Bulletin of The Polish Academy of Sciences-Technical Sciences 65 (6), 805-813 (2017) DOI: 10.1515/bpasts-2017-0089

11. M. Miśkiewicz, K. Makowska, SGEM2017 Conference Proceedings, ISSN 1314-2704, 17 (22), 257-264 (2017) DOI: 10.5593/sgem2017/22/S09 .032 .

12. J. Chróścielewski, M. Miśkiewicz, Ł. Pyrzowski, B. Sobczyk, K. Wilde, Composites Part B-Engineering 126, 153-161 (2017) DOI: 10.1016/j.compositesb. 2017.06.009

13. J. Bien, M. Kuzawa, Archives Of Civil And Mechanical Engineering 15 (4), 1046-1060 (2015) DOI: $10.1016 /$ j.acme.2015.05.007

14. T. Siwowski, M. Kulpa, M. Rajchel, P. Poneta, Composite Structures 206, 814-827 (2018) DOI: 10.1016/j.compstruct.2018.08.048

15. T. Siwowski, D. Kaleta, M. Rajchel, Composite Structures 192, 555-567 (2018) DOI: 10.1016/j.compstruct.2018.03.042

16. M. Salamak, T. Owerko, P. Lazinski, Architecture Civil Engineering Environment 9 (4), 89-97 (2016) DOI: $10.21307 /$ acee-2016-055

17. C. Machelski, M. Hildebrand, Journal of Civil Structural Health Monitoring 5 (1), 1-9 (2014) DOI: 10.1007/s13349-014-0074-7

18. T. Mill, A. Ellmann, M. Kiisa, et al., Baltic Journal of Road and Bridge Engineering 10 (1), 17-27 (2015) DOI: 10.3846/bjrbe.2015.03

19. P. Olaszek, M. Lagoda, C. Ramon, Structure and Infrastructure Engineering 10 (6), 834-842 (2014) DOI: $10.1080 / 15732479.2013 .772212$

20. S. Parivallal, T. Narayanan, K. Ravisankar, et al., Strain 41 (1), 25-30 (2005) DOI: 10.1111/j.14751305.2004.00160.x

21. P. Łaziński, S. Pradelok, Procedia Engineering 161, 530-537 (2016) DOI: 10.1016/j.proeng.2016.08.684

22. C. Machelski, M. Hildebrand, Journal of Civil Structural Health Monitoring 5 (1), 1-9 (2014) DOI: 10.1007/s13349-014-0074-7
23. C. Machelski, Studia Geotechnica et Mechanica 40, 1-7 (2018) DOI: 10.2478/sgem-2018-0020

24. PN-85/S-10030 Bridge structures. Loads (in Polish)

25. J. Chróścielewski, J. Makowski, W. Pietraszkiewicz: Statyka $i$ dynamika powtok wieloptatowych. Nieliniowa teoria $i$ metoda elementów skończonych. IPPT PAN. Warszawa 2004 (in Polish)

26. L. Kwasniewski, H.Y. Li, J. Wekezer, J. Malachowski, Finite Elements in Analysis and

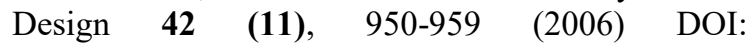
10.1016/j.finel.2006. 01.014

27. J. Szulwic, P. Tysiac, A. Wojtowicz, Coastal Cliffs Monitoring and Prediction of Displacements Using Terrestial Laser Scanning, 2016 Baltic Geodetic Congress (BGC GEOMATICS), IEEE Xplore Digital Library (2016) DOI: 10.1109/BGC. Geomatics.2016.20

28. K. Bobkowska, A. Inglot, M. Mikusova, P. Tysiąc, Polish Maritime Research Special Issue S1 (93) 24, 10-15 (2017) DOI: 10.1515/pomr-2017-0015

29. M. Przyborski, P. Tysiąc, E3S Web of Conferences 26, art. no. 00011 (2018) DOI: 10.1051/ e3sconf/20182600011

30. J. Szulwic, P. Tysiąc, MATEC Web of Conferences 122, art. no. 04004. (2017) DOI: 10.1051/ matecconf/201712204004

31. K. Bobkowska, J. Szulwic, P. Tysiąc, MATEC Web of Conferences 122, art. no. 04001. (2017) DOI: 10.1051/matecconf/201712204001

32. P. Tysiac, Laser Scanning of a Soil-Shell Bridge Structure, 2018 Baltic Geodetic Congress (BGC Geomatics), 250-253 (2018) DOI: 10.1109/BGCGeomatics.2018.00054

33. A. Janowski, W. Kaminski, K. Makowska, J. Szulwic, K. Wilde, The method of measuring the membrane cover geometry using laser scanning and synchronous photogrammetry, Book Series: International Multidisciplinary Scientific GeoConference-SGEM, ISSN 1314-2704 (2015) 